\title{
Impacts and implications of early childhood education social obligations
}

\author{
Judi Randall
}

\begin{abstract}
In 2013, attending an early childhood education (ECE) service became a social obligation for children of beneficiaries in New Zealand. This article draws on stories gathered through interviews in a qualitative study of the effects of ECE social obligations on affected families and whānau (Randall, 2015). This article is intended to stimulate discussion and contribute insight, understanding and awareness to policy makers and educators. Concerns are raised regarding the incorporation of ECE policy within Ministry of Social Development legislation. Previous Work and Income (WINZ) administration errors and the perceived lack of consistency and approachability of WINZ staff raise concerns about their ability to inform and support whānau to locate appropriate ECE. The article highlights the need for quality local, culturally responsive ECE to promote participation, rather than obligatory legislation. Factors of responsive ECE are discussed as well as benefits of integrated services.
\end{abstract}

\section{Introduction}

n 2013, ECE social obligations were introduced through the Social Security (Benefit Categories and Work Focus) Amendment Bill. These obligations require beneficiaries to ensure their children are "enrolled in and attending an approved early childhood education programme from the age of three, until they start school" (Work and Income New Zealand, 2013). This article explores the effects of early childhood education (ECE) social obligations through the stories of affected beneficiary families and whānau, gathered during interviews for an MEd thesis (Randall, 2015).

Analysis of government papers provides the background context and rationale under which this policy was formulated. Ministry of Social Development and Welfare Working Group papers detail that the Welfare Working Group was established in 2010 "to examine ways to reduce long-term benefit dependency in New Zealand for people of working age" (Welfare Working Group, 2011, p. 1). While these working papers advocate for Ministry of Social Development and Ministry of Education collaboration and position the policy as being in children's best interests, it is significant that obligations were not instigated by the Ministry of Education. The mandatory ECE obligations were conceived by the Welfare Working Group and through subsequent Ministry of Social Development welfare reforms with the purpose of reducing long-term benefit dependency.

It can be argued that the context of this policy's conception has produced a targeted policy that lacks the support and provision that could have been foregrounded if the promotion of ECE participation was conceived from the perspective of a child's rights. A framework of child's rights would give primary consideration to the best interests of children rather than impose potentially harmful sanctions. The policy appears to give insufficient 
consideration to children's well-being, with the threat of financial penalties for those who fail to comply. The Social Security (Benefit Categories and Work Focus) Amendment Act 2013 states that beneficiary parents who fail to take all reasonable steps to meet ECE social obligations will be given three reminder opportunities before they are subject to financial sanctions resulting in a 50 percent reduction of their benefit. The Child Poverty Action Group's (CPAG) report, Benefit Sanctions: Creating an Invisible Underclass of Children? argues that this legislation has no "provisions to safeguard the interests of children" (p. 6) and that conditionality attached to core benefits "will always place child welfare outcomes at greater risk" (Wynd, 2013, p. 9).

Since ECE social obligations are relatively recent in New Zealand, there is no scholarly research on the effects of these obligations. The study reported here enables the stories of beneficiaries to be heard and contributes understanding about how beneficiaries perceive and experience this policy. It raises concerns about the policy's ability to adequately address barriers to ECE participation and to the incorporation of ECE policy within Ministry of Social Development legislation.

\section{Theoretical framework and methodology}

The study was carried out for an MEd thesis at the University of Waikato and had research ethics approval from the Faculty of Education Research Ethics Committee. The research design encompassed a qualitative methodology with an interpretive paradigm to ensure that beneficiaries' experiences were heard. Semi-structured interviews alongside a brief background questionnaire were used to gather data.

Eight beneficiary parents of 3- or 4-year-old children were interviewed. Two were fathers, each in full-time training. Six were mothers. Two mothers were in full-time training, two were not in training or paid employment, one was in part-time employment and one had just gained a full-time job at the time of interview.

Two ECE managers, a community ECE team leader, and a kindergarten head teacher, all of whose services included many beneficiary families, were interviewed.

These data were then analysed using thematic analysis. Several main themes discussed in this article raise questions about beneficiary families' right to choose whether their child should attend ECE, the suitability of WINZ to administer ECE obligations, the risks that sanctions place on children's well-being, and the nature and quality of ECE provision.

\section{Choice}

As a result of this legislation, the community ECE team leader and five parent participants felt that the right of choice held by other families in New Zealand about whether to enrol their child in ECE had been taken away from beneficiary families. A common view was that mandatory ECE implies that authorities have little belief in beneficiary parents' ability to care for their own child/ren and provide good educational experiences for them. However, contrary to this perception, parent participants expressed high educational aspirations for their children and seven had already enrolled their children without the need for mandatory legislation. ECE manager participants perceived that families who were not enrolled in ECE were likely facing barriers that hindered participation rather than being reluctant to enrol their child. ECE obligations were perceived to undermine a family's values and choice over whether they want to educate their children at home. One mother described her feelings about her lack of choice:

... it feels like you don't have much control, or ... you gotta do what they say ... so it makes you feel like you've got no choice whether you wanted to home school them, teach them yourself you know, teach, even if you wanted them to stay home, teach them there, your language, your religion, your, you know, you won't have a choice because you have to send them to day care where someone else will teach them what they know. (Rebecca, ${ }^{1}$ parent interview, August 2014)

\section{A case study of Hine}

The following story highlights the barriers one mother, Hine, encountered when enrolling her children in ECE. Hine's story illuminates the need for accessible information and support for parents to assist them to access suitable ECE, and the importance of welcoming and responsive teachers and services.

Hine is a single Mum with three children; Hunter is 15 years, Daniel is four years, and her youngest, Liam, is three years old. She recently moved to a new city and enrolled her middle son, Daniel, at an ECE centre, as she believed he would benefit from being around other children and learning to get along with them.

Daniel struggled to settle at this centre and cried a lot. Hine said he sometimes would almost make himself sick so he would not have to go. Hine felt that her son did not fit in and the staff just left him to cry. She described how the staff expected her to drop her son off and leave straight away. She says it was a kindy that thinks it's good to drop and gap [sic] while your kid's screaming, you know to run away while your kid's screaming and listen on the other side of the fence.

This was something she was clearly not comfortable with. She appeared to feel like an outsider that did not belong and referred to it as a "mean" place. Hine also struggled with the communication at this centre. She explained to the centre manager that she would be late paying her account as WINZ had cut her benefit in error. However, when she went to take Daniel there a few days later the centre handed her a letter which said that because of her unpaid account, Daniel was suspended. The anger and frustration she felt for the centre boiled to the surface and she withdrew him.

She then received a letter from WINZ that informed her Daniel had to be enrolled at an ECE service. At the bottom of the letter it said there was a list of information on centres attached; however, this information was not there.

She went to WINZ and asked where the information was. She voiced her frustration, exclaiming,

"Why do we have to be forced to do this? ... You don't care individually about my son, because he is not your son. The thing is, is that, it could be holding my son back from learning, because I'm forced to put him in somewhere, I don't know where to go."

Hine found WINZ unhelpful and relays how they did not have information on ECE services in her neighbourhood:

"I's like come on, is there none on my side of the tracks? She goes yes, but I can't find the list for that. I's like well how many other people have enquired about this letter. Oh quite a lot. Well then you would think that you would have everything you need for it. That was the other setback about it, is the information you needed to go along with all these kindys and you know with the form you got sent out and all that, they don't even have any of that stuff available if you needed it." 
After the previous ECE experience Hine was quite stressed trying to find a service that Daniel would be happy at. The wording on the WINZ letter led her to believe there was urgency to find a place. This impacted on the whole family. Hunter, aged 15 , played up and missed out on school experiences as Hine was too preoccupied to organise things for him. Hine even took Hunter out of school to get him to help her find childcare for the younger boys.

She did find a place where she felt welcomed. She described how when she visited, the teacher gave her a hug:

“We were just 'Hi, how are you?' and she gave me a hug. And I was like wow ... So the feeling I got from there straight away was I really like this place. You know it just made me feel comfortable, made my son feel so comfortable."

Hine had a bit of a cry and told the teacher how she hated having to enrol her son. The teacher was welcoming and told Hine that she was welcome to stay at the centre as long as she liked. Now as Hine talks about the new centre you can sense the ownership and belonging she feels for the place. She describes how it is a good fit for her family:

"Just the communication from the teachers from the one they're at now, yeah, just to me suited, it was like a big family, not just like I'm here and you're there."

\section{Perceptions of Work and Income}

While social obligations require the children of beneficiaries to attend ECE, WINZ, who administer the policy, do not appear to be equipped to inform and support whānau to locate appropriate ECE. This is compounded by the fact that ECE is regulated and monitored by the Ministry of Education, yet ECE obligations have been legislated by and are enforced by the Ministry of Social Development, thereby resulting in potential lack of cohesion of policy.

Bearing in mind this legislation is enforced through WINZ, parents such as Hine had an expectation that WINZ would be able to provide her relevant local information and support to find a suitable service for her children. However this was not the case when she sought advice and help from WINZ. Lack of local knowledge was reported by participants in this study with some beneficiary families having moved location as a result of changes in their personal lives, and/or to find employment. Six parent participants in this study indicated they were new and unfamiliar with their community and therefore did not have local knowledge of ECE services available for their children.
Through an Official Information Act request, the Ministry of Social Development was asked "What support is available to help families find suitable ECE for their child?" Their spokesperson responded that " $(\mathrm{w})$ here a parent or caregiver needs assistance to meet their social obligations, we proactively work with them and provide information to help them enrol their children in health and education services in their area" (D. Power, personal communication, October 3, 2014). While WINZ may state that they are equipped to provide assistance, Hine's experience shows this was not the reality for her. The staff she encountered did not appear to be trained or readied to proactively work with her, or to provide her with relevant information to find an appropriate ECE service.

In addition to this perceived absence of support, beneficiaries' perceptions (garnered from their previous treatment and communication with WINZ staff) call into question the role of WINZ in supporting beneficiaries to engage in ECE and their ability to administer ECE obligations. A majority of participants shared negative experiences from their encounters with WINZ staff.

One study participant described some WINZ staff as "intimidating”, "judgemental", "bullying", and "unprofessional"; a second participant said about staff "they judge you". Three participants were frustrated that there appeared to be a lack of consistency and competence in staff. While participants acknowledged that some staff were helpful, conversely, other staff were labelled as unsupportive. Parent participants and an ECE team leader observed that the outcome of a visit to WINZ can be based entirely on the staff member encountered. One mother recounted inconsistencies between different staff and her trepidation about being allocated some WINZ staff members:

Kelly: [The case worker said] "Well you're not getting it [payment for a driver's licence] and it's my discretion, so no". I went back two days later to somebody else who turned around and signed the paper for me to go and get [my driver's licence] exactly what, you know, like that. So that just depends on who you see.

Researcher: How do you feel when you are waiting and you are looking to see which person you're going to get today? Kelly: Yeah that's what we do, yeah and we're going "hope we don't get her, oh please don't give us her, oh hope she doesn't give us him either", that's how we are when we used to go there, which is why we try and not even go there, yeah.

(Kelly, parent interview, August 2014).

The lack of consistency between different members of WINZ staff raises questions as to how some staff may interpret the meeting of obligations. ECE social obligations state that a parent must take "all reasonable steps" to enrol a child in ECE. Such wording raises the potential for incongruent interpretations of what constitutes "all reasonable steps". The Official Information Act response positions that "a beneficiary is considered to be taking all reasonable steps to meet their obligations if they have their child's name on the waiting list" (D. Power, personal communication, October 3, 2014). However, beneficiaries appear to be unaware of this option as the letter they receive has no explanation of what is considered to be reasonable steps and makes no reference that being on a waiting list will fulfil such requirements.

Further to inconsistencies, six out of eight of the parent participants reported WINZ administration errors had negatively affected their families. Errors included their benefits being cut, being underpaid, and personal data being misplaced.

Dean, a parent, described how he had his benefit cut off in error. He was attending a course that WINZ had referred him to and told him to complete. Because he was attending his course, as he had been required to do, he was unable to attend an additional appointment WINZ made for him during course time, and as a result WINZ stopped his benefit.

Widowed mum Jo described how a WINZ staff member was unable to find the details of one of her children on their records. The staff member then required Jo to re-provide documentation such as her late partner's death certificate, an upsetting experience for her. Later, a different WINZ staff member indicated that if the first worker had searched the correct file they would have seen that WINZ already had the information.

\section{Experiences of sanctions}

Because they're controlling your money, they control your life. (Rebecca, parent interview, August 2014).

Failure to comply with ECE social obligations can result in financial penalties. Although as at 
June 2014 no beneficiaries had been sanctioned as a result of ECE social obligations (D. Power, personal communication, October 3, 2014), this does not remove the anxiety that the threat of sanctions places on families. Five parent participants, had at some point, received threats of sanctions, and two families had had their benefits cut in error. While the aforementioned sanctions were enacted in connection to perceived failure to meet work expectations (not ECE social obligations), the stories illustrate the fear sanctions arouse and how errors, such as those Dean experienced, affect a family's ability to provide for their children.

It was quite hard, yeah I had to, cause we couldn't really afford food, I had to send my partner-my wife and my son out of the house to her Dad's place so that they could get fed. Because we didn't have enough money for food. (Dean, parent interview, June 2014).

The enlisting of sanctions to reinforce ECE obligations is very likely to lead to financial hardship and place stress on families. Such outcomes have the potential to hurt the very children that this legislation is purportedly meant to help.

\section{Quality}

New Zealand and international research establish that for ECE to be most beneficial to children it must be of good quality (Campbell et al., 2002; Mitchell et al., 2008). Although this study did not assess the quality of the services that the participants' children were attending, three participants shared their observations of poor quality practice. These incidents included descriptions of bullying, lack of resources such as books, and inadequate supervision and interaction by staff. In addition to participants' stories, the New Zealand Herald published a list of incidents that happened in ECE services that had been reported to the Ministry of Education in the last year. These included: a teacher bit a child; staff smacked children; a child fell off a slide and did not receive medical treatment; children not given their prescribed medicine; a child left a centre and was found on the street, while the centre was unaware the child was missing; and children had food withheld from them (Tait, 2013, 10 October).

Other key elements of quality are inclusivity and responsiveness to individual needs and values (Mitchell et al., 2008; Ritchie \& Johnson, 2011). Hine's case study illustrates her and her son's struggle to find a sense of belonging in a service that appeared to lack empathy and understanding of their situational circumstances. The ECE service made Hine feel she was not welcome to stay.

Difficulties expressed by participants in this study highlight the need for information, accessibility, support and understanding. Collaboration and the building of relationships between ECE providers and the community can help break down barriers to participation. Ensuring enrolment processes are inclusive and the provision of a welcoming and accommodating environment can enable a smoother transition for both parents and their children. Examples of such responsive processes came through in participant interviews and have implications for practitioners.

\section{Relationships and collaboration}

This study identified that parents perceived a sense of belonging in ECE services that welcomed families on their own terms and placed emphasis on building relationships with the community. Kindergarten head teacher Fiona had many new beneficiary families enrol at her kindergarten. She spoke of the importance of building relationships with the community and how whānau heard about it being a welcoming and approachable place through word of mouth. Her kindergarten took the initiative to collaborate with other services and placed information about the kindergarten at WINZ, as well as at other community centres.

\section{The enrolment process}

To assist families through personal barriers, consideration needs to be given to how they may feel coming into a possibly unfamiliar environment. Four parents in this study expressed a lack of confidence and nervousness about enrolling their children as a result of ECE being unfamiliar territory for them, past experiences, and because of the protectiveness they felt for their child.

One mother, Jo, expressed her nervousness about her son attending childcare because he had health complications. Another mother, Kelly, described her reluctance to enrol her twins, but explained that with the understanding and support of her children's ECE service she was able to make the transition:

They supported me the whole way with them and yeah I started doing voluntary work in the kitchen, that way they were just on the other side of me, you know. And then slowly I made my way in the hall, to garage sales helping and you know, I just loved helping out, so I just kept coming back and then I started relieving for the cleaners when they couldn't come in, and the kitchen lady when she couldn't come in ... The cleaning came available they told me to put an application in, so I did, yeah. Which made it easy cause I was still with my boys and they were still getting an education I know I needed them to have and I was back to work. (Kelly, parent interview, August 2014)

ECE managers, Fiona and Debbie, have both sought to understand how their processes may feel to parents and adapted the way they greet new families and the amount of time they allow for the enrolment process.

The families that are coming because of the policy, they have different needs and different ways of supporting them and I guess we've, we talk about it a lot. Sort of very shy at the gate, or head down or, just not sure what they're asking for or anything, so. You just have a different approach for each person. (Fiona, kindergarten head teacher interview, August 2014)

An inclusive and supportive environment can help aid families through the transition process, especially those who are feeling apprehensive about their children attending ECE. As ECE team leader Debbie identified "the way a parent feels about their child going into ECE has a huge effect on how the child enters and how they feel" (Debbie, ECE team leader interview, July 2014). Enforced participation, such as these obligations, without any provision of support has the potential to adversely impact on young children's transition into ECE.

\section{Integrated ECE and family support}

Integrated ECE services enable opportunities for family engagement, they provide a hub for their local community, break down barriers to access and thereby enable families to be involved, empowered, and supported (ClarkinPhillips, 2012; Clarkin-Phillips \& Carr, 2014).

Three mothers provided stories of how the integrated ECE service their child/ren attended supported their children to access ECE and had resulted in positive outcomes for both them and their children. As well as providing a caring, 
quality environment for young children, the service has embraced a holistic philosophy to support families. With a kitchen at its hub and seating, it provides a place for people to meet and connect. The service offers wraparound services (funded through surpluses and sponsorship) and opportunities to empower parents and support them to provide for their families; these services and opportunities include the sharing of skills, parenting programmes, budgeting, food banks, volunteer work, access to work opportunities, and counselling.

\section{Conclusion}

The possible negative outcomes for children's well-being from the enforcement of social obligations through financial sanctions needs further consideration. Obligatory ECE has sought to place responsibility on beneficiaries, but seems to have failed to adequately address barriers that impede participation or address the need for access to high quality suitable ECE. Encouraging participation for all children through the provision of local, culturally responsive programmes is more likely than social obligations to enable participation.

Responsive ECE services are able to support participation and a sense of belonging for families through providing accommodating, high quality, empowering ECE programmes. Integrated services are additionally able to provide families with wraparound services.

In light of beneficiaries' experiences with WINZ and from the perspective of what is best for children and their whānau, it appears problematic for this ECE policy to be administered by WINZ. To ensure coherent and co-ordinated policy which is centred on the child's rights, I contend that all ECE participation initiatives need direction and administration from the Ministry of Education. This is more likely to allow supportive policy and provision that enables families to overcome the barriers that prevent their children from accessing quality ECE.

\section{Acknowledgements}

I would like to express my gratitude to the participants in this study for so generously sharing their stories. I am immensely grateful for the wise guidance and support of my master's supervisor Associate Professor Linda Mitchell. I would also like to acknowledge the University of Waikato Masters Research scholarship which provided the financial support that enabled me to undertake this research.

\section{Note}

1 Pseudonyms have been used for all participants, community services, and locations in this article to protect anonymity.

\section{References}

Campbell, F. A., Ramey, C. T., Pungello, E., Sparling, J., \& Miller-Johnson, S. (2002). Early childhood education: Young adult outcomes from the Abecedarian project. Applied Developmental Science, 6(1), 42-57. http:// dx.doi.org/10.1207/S1532480XADS0601_05

Clarkin-Phillips, J. (2012). Connecting curriculum and policy to assist families' aspirations. Waikato Journal of Education, 17(1), 17-27. http:// dx.doi.org/10.15663/wje.v17i1.21

Clarkin-Phillips, J., \& Carr, M. (2014). An affordance network for engagement: Increasing parent and family agency in an early childhood education setting. European Early Childhood Education Research Journal, 20(2), 177187. http://dx.doi.org/10.1080/135029 3X.2012.681130

Mitchell, L., Meagher-Lundberg, P., Taylor, M., Calcutt, T., Kalavite, T., Kara, H., \& Paki, V. (2013). ECE participation programme evaluation. Delivery of ECE participation initiatives: Baseline report. Retrieved from http:// www.educationcounts.govt.nz/publications/ ECE/ece-participation-programme-evaluation Mitchell, L., Wylie, C., \& Carr, M. (2008). Outcomes of early childhood education: Literature review. Wellington: Ministry of Education.

Randall, J. (2015). Impacts of early childhood education social obligations on families and whänau. Unpublished master's thesis, University of Waikato.
Ritchie, J., \& Johnson, A. (2011). Early childhood care and education. In M. C. Dale, M. O'Brien, \& S. St John (Eds.), Left further behind: How policies fail the poorest children in New Zealand. (pp. 159-174). Auckland: Child Poverty Action Group.

Tait, M. (2013, October 10). "Horror" tales at preschools. The New Zealand Herald. Retrieved from http://www.nzherald.co.nz/nz/news/ article.cfm?c_id=1\&objectid=11137696

Vandenbroeck, M., \& Lazzari, A. (2014). Accessibility of early childhood education and care: A state of affairs. European Early Childhood Education Research Journal, 22(3), 327-335. http://dx.doi.org/10.1080/135029 3X.2014.912895

Welfare Working Group. (2011). Reducing long-term benefit dependency recommendations. Retrieved from http://igps.victoria.ac.nz/ WelfareWorkingGroup/Downloads/Final\%20 Report/WWG-Final-RecommendationsReport-22-February-2011.pdf.

Work and Income New Zealand. (2013). Obligations for people on a benefit with dependent children. [Fact sheet]. Retrieved from http:// www.workandincome.govt.nz/documents/ brochures/obligations-for-people-on-a-benefitwith-dependent-children.pdf

Wynd, D. (2013). Benefit sanctions: Creating an invisible underclass of children? Retrieved from http://www.cpag.org.nz/assets/ Backgrounders/2-0\%2028509\%20Benefit $\% 20$ Sanctions\%20Report\%20Sept $\% 202013 . p d f$
Judi Randall has been working in the early childhood care and education sector for the past twenty years. She has recently completed her Master of Education through the University of Waikato.

Email: mikejudiळvodafone.co.nz 